\title{
Chapter 4 \\ Long-Term Tracking of Multiple Benefits of Participatory Forest Restoration in Marginal Cultural Landscapes in Himalaya
}

\author{
Krishna G. Saxena, Kottapalli S. Rao, and Rakesh K. Maikhuri
}

\begin{abstract}
The literature is abound with references to the potential of indigenous and local knowledge (ILK) for sustainable landscape management, but empirical on-theground efforts that demonstrate this potential are still lacking. To identify interventions for improving the effectiveness and efficiency of forest restoration, participatory trials were set out in the Indian Himalaya, where per capita degraded land far exceeds per capita cropped/healthy forest land. Treatments were designed based on pooled indigenous and scientific knowledge taking into account farm-forest-livelihood interactions in cultural landscapes. The multipurpose tree-bamboo-medicinal herb mixed restoration plantation reached a state of economic benefit/cost ratio $>1$ in the eighth year and recovered $30-50 \%$ of flowering plant species and carbon stock in intact forest. The communities maintained but did not expand restoration in the absence of policies addressing their genuine needs and aspirations. Transformative change for sustainable restoration would include (1) nesting restoration in participatory, long-term, adaptive and integrated landscape development programmes, (2) formally involving communities in planning, monitoring, bioprospecting, and financial management, (3) assuring long-term funding but limited to the inputs unaffordable for local people, (4) stimulating the inquisitive minds of local people by enriching ILK and cultural heritage, (5) convincing policymakers to provide the scientific rationale behind policy stands, to support the regular interactions of communities with researchers, traders, and industrialists, to commit to genuine payment for ecosystem services in unambiguous terms at multiple spatial (household, village and village cluster) and temporal (short, medium and long-term) scales, and to
\end{abstract}

K. G. Saxena $(\triangle)$

School of Environmental Sciences, Jawaharlal Nehru University, New Delhi, India

K. S. Rao

Department of Botany, Delhi University, Delhi, India

R. K. Maikhuri

Department of Environmental Sciences, HNB Garhwal University (Central University),

Srinagar, India

(C) The Author(s) 2021

61

M. Nishi et al. (eds.), Fostering Transformative Change for Sustainability in the

Context of Socio-Ecological Production Landscapes and Seascapes (SEPLS),

https://doi.org/10.1007/978-981-33-6761-6_4 
support long-term participatory action research for development of "landscape restoration models" in varied socio-ecological scenarios.

Keywords Bamboo $\cdot$ Biodiversity $\cdot$ Carbon stock $\cdot$ Medicinal plants $\cdot$ Farm . Integrated landscape management $\cdot$ Livelihood $\cdot$ Multipurpose trees $\cdot$ Payments for ecosystem services $\cdot$ Temperate

\subsection{Introduction}

Ecological restoration became a global priority at the turn of the twenty-first century, with the Convention on Biological Diversity aiming to restore at least $15 \%$ of degraded ecosystems by 2020, the Bonn Challenge to bring 350 million hectares of degraded and deforested land into restoration by 2030, and the United Nations declaring 2021-2030 as the Decade on Ecosystem Restoration. The envisaged targets can be achieved only through transformative change in current restoration approaches (IPBES 2019). A realisation of the key role of socio-economic and institutional factors in sustainable restoration (Chazdon et al. 2016; Reed et al. 2016) paved the way for community-centred forest landscape restoration and forest management (Baynes et al. 2015). Lately, the potential of indigenous and local knowledge (ILK) in overcoming technical barriers to restoration has also been recognised (Reyes-Garcia et al. 2019). Nonetheless, empirical efforts demonstrating this potential are rare (He et al. 2009; Stanturf et al. 2014). Forest restoration has been attempted largely through sponsored projects (Le et al. 2012; Burton 2014) and sustainability after cessation of funding has rarely been assessed (Rudel et al. 2005; Chazdon et al. 2016; Reed et al. 2016).

Himalaya is a biodiversity hotspot facing the entwined challenges of enhancement of livelihoods and environmental conservation. Forest restoration is a win-win option for conserving biodiversity, mitigating climate change and enhancing livelihoods (Brandt et al. 2017; Forest Survey of India 2019). We elaborate herein on the transformative change needed for sustainable forest restoration based on a participatory trial in a temperate socio-ecological production landscape.

\subsection{Materials and Methods}

\subsubsection{Study Area}

At the time of initiation of the study in 1991, Khaljhuni was a typical marginal, un-electrified village of the moist temperate region around the Nanda Devi Biosphere Reserve, a UNESCO World Heritage Site. The village territory comprised 68 hectares of terraced private farms and 436 hectares of community forests (Fig. 4.1 and Table 4.1). 


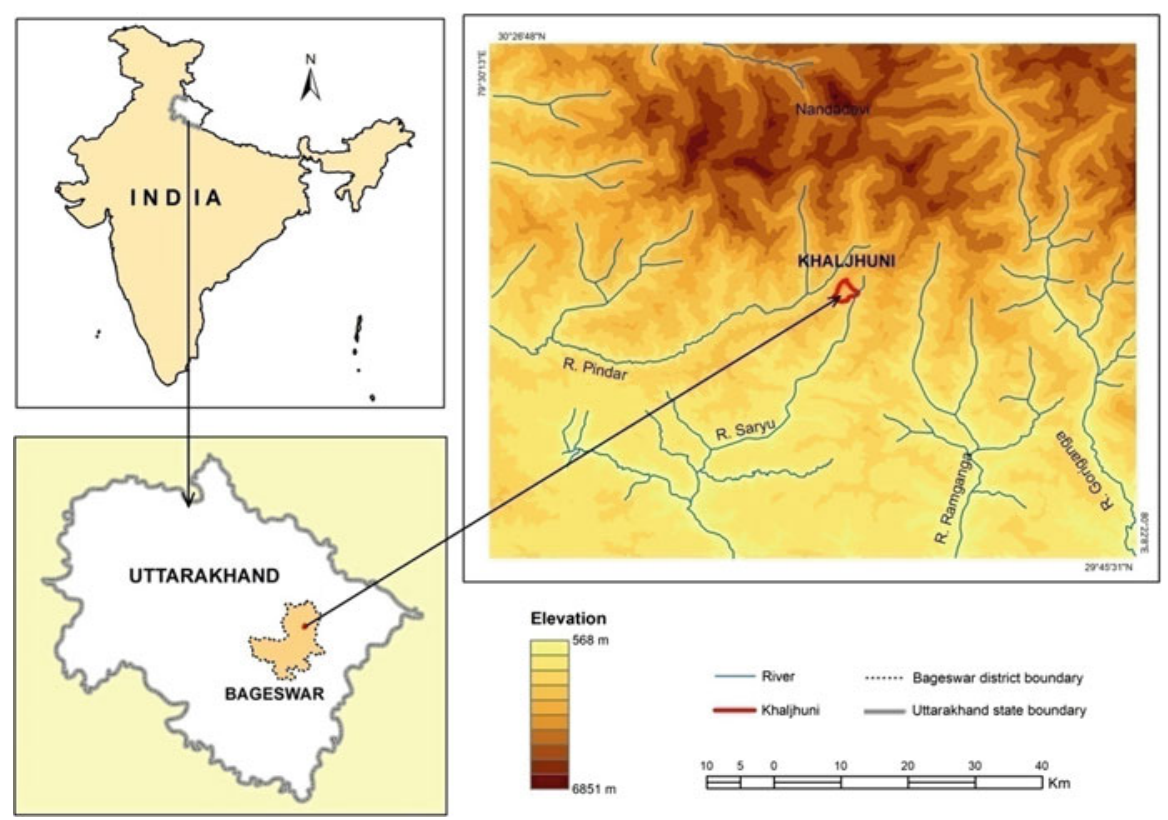

Fig. 4.1 Village of Khaljhuni in Central Himalayan Region of India

Table 4.1 Basic information of the study area

\begin{tabular}{l|l}
\hline Country & India \\
\hline Province & Uttarakhand \\
\hline District & Bageswar \\
\hline Municipality & n.a. \\
\hline Size of geographical area (hectares) & 5000 \\
\hline Number of indirect beneficiaries (persons) & 10,000 \\
\hline Dominant ethnicity(ies), if appropriate & n.a. \\
\hline Size of case study/project area (hectares) & 600 \\
\hline Number of direct beneficiaries (persons) & 340 \\
\hline Dominant ethnicity in the project area & n.a. \\
\hline Geographic coordinates (latitude, longitude) & $30^{\circ} 2^{\prime} 6.72^{\prime \prime} \mathrm{N} ; 79^{\circ} 35^{\prime} 52.80^{\prime \prime} \mathrm{E}$ \\
\hline
\end{tabular}

Cultural heritage concerning the treatment of agricultural abandonment and purchase of foodgrains, as well as hiring of labour, from outside the village as evil omens, had checked agricultural expansion and strengthened social bonding at the time of the trial's initiation in 1991. Around 305 hectares of forest were intact and 131 hectares were severely degraded. The degraded forests were nearer to the dwellings than the intact forests. Degradation occurred because of lack of restoration after logging in 1910 by the Forest Department of the colonial government. The Department had created community forests to alleviate people's resentment against its disregard for their well-being and cultural heritage, which viewed logging as a 
bad omen, and had sanctioned income from wild non-timber forest products only to small farm holders, allowing only collection of edible/medicinal products from forests which checked storm flows and recharged springs. Confinement of ILK to passive forest restoration and prohibition of developing tree-crop mixed systems on forest land led the community to restore traditional practices in the intact forest and to use logged areas as free pasture, driving them to a severely degraded state.

\subsubsection{Participatory Community Forest Restoration Trial}

People's expectations and underpinning reasons for being against forest restoration were discerned from participatory discussions. People desired early and high income by growing medicinal herbs and understory bamboo. They dismissed the planting of trees due to long waiting periods for production of non-timber commodities, cultural restraints on income from timber, as well as hesitated to make cash or labour contributions to establish practices with uncertain returns. They seemed willing to reciprocate support for restoration addressing their expectations by (1) free sharing of ILK, deploying surplus physical resources and social capital, and maintaining/ expanding the trial once it reached a state of economic benefit/cost ratio of $>1$, and (2) accommodating the concerns of other stakeholders. They knew gregarious flowering induced mass mortality of bamboo but reconciled it with high productivity.

People gave up their initial reservations on planting trees after learning from participatory discussions that: (1) scientific knowledge lacked tested methods of cultivation of medicinal herbs/understory bamboo, (2) some multipurpose trees valued by them were likely to facilitate them, (3) organic branding of walnut/ honey will fetch premium prices, (4) payments for carbon sequestration were quite likely in near future, and (5) availability of tree products close to dwellings would save time/labour spent on collection from distant forests and would unleash opportunities for raising crop yields by eliminating tree-crop interferences. Ultimately, the community decided to establish a mixed plantation of trees, viz. Aesculus indica (horse chestnut), Quercus leucotrichophora (oak) and Juglans regia (walnut), a short bamboo (Thamnocalamus spathiflorus), and medicinal herbs viz. Aconitum heterophyllum, Angelica glauca, Picrorhiza kurroa and Rheum australe in an eighthectare plot and maintain/expand it once economic outputs exceeded input costs. Financial support was terminated 7 years after planting when economic benefit/cost ratio crossed the mark of one (Rao et al. 1999), while participatory discussions and monitoring of the restored forest and competing land uses/economic activities continued. 


\subsubsection{Data Collection}

Density of surviving plants, height/girth growth of trees/bamboo, biomass, soil carbon stocks and material inputs/outputs were measured after 1, 7, 10, and 20 years in the trial area and also in agricultural land, intact forests and degraded forests outside the trial area. All households were surveyed to assess changes in human/livestock population, land use-land cover, harvests and income. People's perceptions about the present trial and conservation development policies were ascertained from open-ended discussions, and researchers' deductions were informed in traditional open village assemblies in accordance with traditional norms (Rao et al. 1999; Maikhuri et al. 2000; Semwal et al. 2013).

\subsection{Results}

\subsubsection{On-Site Outcomes and Impacts}

\subsubsection{Unanticipated Problems and Responses}

Bamboo suffered gregarious flowering-induced mass mortality in the tenth year (2 years after cessation of funding) when it was at peak growth (80\% of aboveground biomass). Economic loss from bamboo was far less than the gain from walnut, which coincidently started fruiting in the same year. At this time, people also felt a threefold increase in crop/beehive damage from bears and porcupines. People viewed this problem as a combined outcome of the decline in traditional collective mechanisms for dispelling harmful wildlife, facilitation of wildlife movement by bridges constructed over rivers/streams with road expansion, the wildlife sink function of the restored forest, and the focus on charismatic top carnivores (leopards/tigers) and their preferred ungulate preys in protected area management. Further, they envisioned that factors increasing pressure on intact forest (population growth, lack of cost-effective alternatives to timber/wood used for warmth, and cultural obligations of sharing resources with neighbouring communities that have lost their forests due to common amenities like electricity/road) would outweigh the ones decreasing pressure (access to subsidised cooking gas, modern medicine, vermicompost, subsidised food grains, and wage employment) in the near future. Comprehending their ILK, people transplanted wild saplings of Alnus nepalensis (Nepalese alder) in gaps for its fast growth in exposed nutrient poor soils, negative association with wildlife and timber value. This species was excluded in the initial planting when wildlife intrusion was limited, insect pests thriving on it threatened crops that met local food needs in the absence of external food supply, and there was yet a lack of envisioning of timber scarcity in future. 


\subsubsection{Species Selection, Performance and Ecological Recovery}

People's selection of species was guided solely by direct economic benefits in the initial treatment and by both direct and indirect benefits in gap filling. Coincidently, species chosen for economic benefits were diverged in respect to leaf dynamics, nutrient requirements, shade tolerance and rooting patterns. ILK about fast growth of bamboo and alder in open habitats turned out to be true, though it altogether lacked underlying biological mechanisms. Naturally regenerated species shared just six percent of above-ground biomass after 20 years.

The rate of economic returns from the 20-year-old restored forest was higher than both the intact forest and cropland. On the other hand, the intact forest had better structure (canopy density, vertical stratification, and basal area) and higher regulating (carbon stock) and supporting (plant biodiversity) ecosystem services than the restored forest. Restoration over 20 years resulted in recovery of hardly $50 \%$ of flowering plant species and carbon stock in the intact forest. Species of high conservation value, the transplanted medicinal herbs, were altogether absent in cropland and untreated degraded forest (Table 4.2).

Time scale and accounting of biomass removals, below-ground organs and soil were significant determinants of carbon sequestration rate (Table 4.3).

\subsubsection{Off-Site Impacts and Outcomes}

There were two off-site impacts of the trial. First, three farmers started cultivating medicinal herbs on their private farms, which was boosted by financial support from National Medicinal Plants Board set up in 2000. The majority attributed non-adoption of this innovation to their exclusion from the scheme and hurdles in marketing. Secondly, 23 families leased out abandoned farms to a pharmaceutical company in 2005 for an annual income of Rs. $5000 \mathrm{ha}^{-1}$ from the lease fee for 30 years. The company planted yew (Taxus baccata), which people used for preparing a health drink and for making the mainframes of houses. Extraction of the anti-carcinogenic drug paclitaxel (Taxol) by the company was outside the ILK domain. With the passage of time, people realised that the income from leasing was at the expense of land degradation (in the absence of manuring and weeding as yew was a stress tolerant species), their economic exploitation (rent being a fraction of the income to the company from Taxol), stagnation of ILK (exclusion of people from industrial processing), weakening of social bonding (the company negotiated with individuals) and illicit harvests from state forests at the company's behest. This realisation, a spin-off benefit from consistent monitoring, introspection, contemplation, social learning and adaptive responses learnt from the trial, led to a collective decision to defer new lease proposals. Further, conjecturing ILK as the foundation of Taxol discovery, people envisioned development of new commercial products from horse chestnut seeds and Prinsepia utilis/Neolitsea pallens seeds, used when crops 
Table 4.2 Economic returns, vegetation structure, plant species richness and carbon stock in restored forests after 20 years, and other land uses (intact forest, degraded forest, cropland, and abandoned cropland) in the Khaljhuni socio-ecological production landscape

\begin{tabular}{|c|c|c|c|c|c|}
\hline & $\begin{array}{l}\text { Restored forest } \\
\text { after } 20 \text { years }\end{array}$ & Intact forest & $\begin{array}{l}\text { Degraded } \\
\text { forest }\end{array}$ & Cropland & $\begin{array}{l}\text { Abandoned } \\
\text { cropland }\end{array}$ \\
\hline \multicolumn{6}{|c|}{ Economic value of produce (Rs/ha/year) } \\
\hline Timber $^{\mathrm{a}}$ & - & 700 & - & - & - \\
\hline Fuelwood $^{\mathrm{a}}$ & 747 & 1569 & 431 & 312 & 165 \\
\hline Fodder $^{\mathrm{a}}$ & 432 & 168 & 192 & 84 & 81 \\
\hline $\begin{array}{l}\text { Bamboo- } \\
\text { culms }^{\text {a }}\end{array}$ & 5550 & 178 & - & - & - \\
\hline $\begin{array}{l}\text { Bamboo-- } \\
\text { seeds }\end{array}$ & - & 200 & - & - & - \\
\hline $\begin{array}{l}\text { Medicinal } \\
\text { herbs }\end{array}$ & 902 & 267 & 163 & 176 & 121 \\
\hline Lichens & - & 97 & - & - & - \\
\hline Leaf litter ${ }^{a}$ & - & 137 & - & - & - \\
\hline Foodgrains & - & - & - & 21,320 & - \\
\hline Fruits & 27,360 & 240 & 0 & 360 & 0 \\
\hline All products & 34,991 & 3556 & 786 & 22,252 & 367 \\
\hline \multicolumn{6}{|c|}{ Vegetation structure and ecosystem functions } \\
\hline $\begin{array}{l}\text { Canopy } \\
\text { density }(\%)\end{array}$ & $40-60$ & $>70$ & $<5$ & $<5$ & $10-20$ \\
\hline $\begin{array}{l}\text { Vertical } \\
\text { stratification }\end{array}$ & $\begin{array}{l}\text { Upper canopy } \\
\text { of } 3-7 \mathrm{~m} \text { tall } \\
\text { planted trees, } \\
\text { lower canopy } \\
\text { of } 1-2 \mathrm{~m} \text { tall } \\
\text { naturally } \\
\text { regenerated } \\
\text { trees and }<1 \mathrm{~m} \\
\text { tall ground } \\
\text { vegetation }\end{array}$ & $\begin{array}{l}\text { Upper canopy } \\
\text { of } 15-25 \mathrm{~m} \text { tall } \\
\text { trees, lower } \\
\text { canopy of } \\
5-10 \mathrm{~m} \text { tall } \\
\text { trees and } \\
1-2 \mathrm{~m} \text { tall } \\
\text { ground } \\
\text { vegetation }\end{array}$ & $\begin{array}{l}\text { Isolated } \\
1-3 \mathrm{~m} \text { tall } \\
\text { trees and } \\
\text { lack of strat- } \\
\text { ification of } \\
\text { tree canopy }\end{array}$ & $\begin{array}{l}\text { Isolated } \\
7-12 \mathrm{~m} \text { tall } \\
\text { trees and } \\
\text { lack of strat- } \\
\text { ification of } \\
\text { tree canopy }\end{array}$ & $\begin{array}{l}\text { Isolated } \\
3-5 \mathrm{~m} \text { tall } \\
\text { trees and } \\
\text { lack of strat- } \\
\text { ification of } \\
\text { tree canopy }\end{array}$ \\
\hline \multicolumn{6}{|c|}{ Number of plant species } \\
\hline Trees & 8 & 21 & 2 & 5 & 6 \\
\hline $\begin{array}{l}\text { Shrubs/ } \\
\text { bushes }\end{array}$ & 3 & 12 & 5 & 3 & 3 \\
\hline Bamboos & 1 & 3 & 0 & 0 & 0 \\
\hline $\begin{array}{l}\text { Herbs other } \\
\text { than grasses }\end{array}$ & 7 & 27 & 14 & 5 & 11 \\
\hline Grasses & 19 & 7 & 19 & 11 & 16 \\
\hline All species & 38 & 70 & 40 & 24 & 36 \\
\hline \multicolumn{6}{|c|}{ Carbon stock (Mg carbon/ha) } \\
\hline $\begin{array}{l}\text { Below- } \\
\text { ground }\end{array}$ & 33.6 & 189.6 & 19 & 15.8 & 10.4 \\
\hline
\end{tabular}

(continued) 
Table 4.2 (continued)

\begin{tabular}{l|l|l|l|l|l}
\hline & $\begin{array}{l}\text { Restored forest } \\
\text { after 20 years }\end{array}$ & Intact forest & $\begin{array}{l}\text { Degraded } \\
\text { forest }\end{array}$ & Cropland & $\begin{array}{l}\text { Abandoned } \\
\text { cropland }\end{array}$ \\
\hline $\begin{array}{l}\text { Above- } \\
\text { ground }\end{array}$ & 85 & 113.8 & 28.8 & 66.7 & 27.7 \\
\hline Total & 118.6 & 303.4 & 47.8 & 82.5 & 38.1 \\
\hline
\end{tabular}

Note: Provision of payments for regulating/supporting ecosystem services did not exist

${ }^{a}$ Social norms permitted sale of products only by small farm holders/weaker families to large farm holders/affluent families within the village

Table 4.3 Changes in carbon sequestration rates with progression of participatory forest restoration trial in village Khaljhuni, Central Himalaya, India

\begin{tabular}{l|l|l|l}
\hline $\begin{array}{l}\text { Carbon sequestration rate } \\
\left(\mathrm{Mg} \mathrm{carbon} \mathrm{ha}^{-1} \text { year }^{-1}\right)\end{array}$ & $\begin{array}{l}\text { Initial 7 years of } \\
\text { restoration }\end{array}$ & $\begin{array}{l}\text { 8th to 20th year of } \\
\text { restoration }\end{array}$ & $\begin{array}{l}\text { Average over } \\
\text { 20 years of restoration }\end{array}$ \\
\hline \multicolumn{4}{|l|}{} \\
\hline Above-ground & 1.06 & 0.75 & 0.86 \\
\hline Excluding biomass utilised & 1.06 & 3.15 & 2.85 \\
\hline Including biomass utilised & 2.29 & 2.39 & 2.80 \\
\hline Below-ground $^{\text {a }}$ & 3.55 &
\end{tabular}

${ }^{a}$ Includes carbon in complete soil profile

failed as a staple food and an edible oil source, respectively, and from Juglans regia, used in healthcare/dyeing/pest control.

\subsubsection{Khaljhuni Cultural Landscape Over the 1991-2011 Period}

Abandonment of cropping initiated in 2000 covered 29\% of farm area by 2011 due to: (1) failure of ILK-based alder planting in checking wildlife menace and inability of government agencies in developing solutions to the problem, (2) lack of policy for compensating crop/honey losses due to wildlife, (3) land holdings becoming too small (0.2 ha per capita in 2011) to secure livelihoods and (4) decline in cultural values prohibiting agricultural abandonment and fostering collective wildlife control due to access to subsidised food grains and acculturation to improved accessibility (distance to road reduced to $6 \mathrm{~km}$ in 2011, from $14 \mathrm{~km}$ in 1991). Forest recovery failed in abandoned farms as a result of the open-access status of unleased farms and stunted yew growth in leased/protected farms.

Government agencies planted conifers on seven hectares of degraded community forest between 2006-2007, engaging local people as wage labourers. The plantation suffered a $100 \%$ mortality within a year due to fires set by the people themselves, who value herbaceous forage more than conifers. Administrative machinery was too weak to check illicit forest fires and private farm leasing.

People listed many reasons behind the failed expansion of the trial: (1) it could not mitigate the new wildlife menace problems, decline in the demand for bamboo 
handicrafts and competition/uncertainties in walnut/medicinal herb markets; (2) it did not satisfy new aspirations viz., freedom to harvest and market all forest products, establishment of value-added facilities within the village and increase in quantum of government support for restoration; (3) technological stagnation created a mindset of looking down upon the traditional labour-intensive production system; and (4) it could not compete with new opportunities for income from caterpillar fungus (Cordyceps sinensis) and government-funded infrastructure development projects in the absence of protected markets for restoration products and commitments to payments for ecosystem services. Agricultural abandonment nullified restoration-mediated carbon sequestration.

\subsection{Discussion}

\subsubsection{Socio-Ecological Diversity}

Subjective carving of community forests resulted in enormous variation in their extents, accessibility and ecological status. It is common to observe communities conserve intact forests and restore selectively logged forests vast enough to secure their essential needs by deploying their ILK and social capital centred around passive restoration. Because of cultural restraints on the timber trade, the intact community forests of Khaljhuni were more efficient in storing carbon (Buffum et al. 2008; Sharma et al. 2010; Pandey et al. 2014) and harbouring species of high conservation (Maikhuri et al. 2000; Adnan and Hölscher 2011) and ecological values (Bhadauria et al. 2012) than the ones managed by the communities free from such restraints. On the other hand, intact forest patches lacking religious value and too small to meet subsistence needs, recharge potable water sources, mitigate floods and to stabilise slopes, suffered from illicit logging by outsiders and then encroachment by local people (Semwal et al. 2004; Wakeel et al. 2005). Due to increasing integration into the mainstream, Khaljhuni people aspired for a quantum leap rather than an incremental rise in income, feasible only by active restoration lacking in ILK. Divergent from people's expectations, conventional restoration targeted forest area expansion to cover two-thirds the area of mountains and one-third the area of the country at the time of trial initiation in the early 1990s.

\subsubsection{Environment-Knowledge-Culture-Policy Interlinkages}

The initial demand for growing marketable herbs/short bamboo was a combined reflection of the people's aspirations for early and high income and their ignorance of scientific knowledge (Guariguata et al. 2010; Ashton et al. 2014) and the expectations of other stakeholders. Participatory discussions enriched ILK and motivated people to minimise trade-offs between immediate economic and long-term 
ecological benefits from restoration (Yami et al. 2013; Andrews and Borgerhoff Mulder 2018). Attention to non-material benefits and people's priorities, which were excluded in top-down restoration, enabled people to (1) conceive new ideas viz., alder planting in gaps in the restored plot and medicinal herb cultivation in private farms, and visualisation of ILK-based new commercial products, (2) revise/rectify based on new learnings reflected from inclusion of tree planting, deferring of new lease proposals and abandonment of cultural values forbidding income even from over-mature/dead/diseased trees, and (3) offer in-kind contributions which reduced treatment establishment (Rao et al. 1999) and monitoring costs (Evans et al. 2018). ILK has been increasingly recognised as an under-exploited resource and community participation as a means of cost-effective forest management and inclusive development worldwide after 1980.Yet, forest restoration planning, monitoring and financial management remains the state monopoly. Top-down restoration projects continue to thrive as a result of projection of their success based on achievement of planting targets rather than the magnitude of ecological recovery (Le et al. 2012; Dudley et al. 2018). These projects serve the vested interests of a few officials and elected representatives more than community well-being (Barr and Sayer 2012; Baynes et al. 2015). Likewise, bioprospecting remains the monopoly of megaindustries in the absence of strict enforcement of free, prior and informed consent procedures and ambiguous benefit-sharing provisions (Maikhuri et al. 2004).

Unlike conventional projects treating people solely as beneficiaries, this project involved them as responsible stakeholders owning all decisions, collecting scientific data and maintaining expenditure accounts jointly with the researchers. Following the traditional norms, final decisions were made by consensus in an open assembly steered by the community leaders and facilitated by the researchers (Rao et al. 1999). Whole-hearted community participation thus derived from researchers appreciating and enriching ILK and cultural heritage, recognising people's needs/aspirations, living with them, establishing a transparent expenditure accounting system and earnestly following the principles of co-management (Berkes 2009). Voluntary maintenance from the eighth year onwards testifies that people tend to honour their informal commitments and take collective action when they encounter anticipated shocks like bamboo flowering. Nonetheless, the trial succeeded in securing investment in restoration, but not in its voluntary expansion or upgradation. A quantum rise in effectiveness and efficiency of current forest restoration approaches is the key transformative change needed to arrest/reverse global deforestation and forest degradation. The present study unveils that this change is feasible from a set of concomitant policy changes for (1) harnessing and enriching ILK and cultural heritage, (2) motivating people to contribute surplus physical resources, (3) making people a formal party in designing and monitoring treatments and financial management, (4) rescuing people from unanticipated problems like excessive wildlife intrusions and economic exploitation by industries and traders whose mitigation is beyond their knowledge and capacity, and (5) nesting restoration in long-term and adaptive landscape management-cum-livelihood enhancement plans.

Policies have changed, but are far from the expectations of people and initiatives in other countries (Berkes 2009; Liu et al. 2016). Lack of holistic and integrated 
landscape management approaches advocated since the 1980s manifested in decline in competitiveness of forest restoration. With increasing education and awareness, people are becoming disgusted with policy elements lacking scientific and/or socioeconomic rationale: (1) transfer of only $18 \%$ of forest area taken over from them in the nineteenth century and community empowerment just to regulate subsistence uses in an era of economic globalisation, (2) meager financial support for ILK-based treatments (Derak et al. 2018) and persistence of cultural heritage favouring equity, community solidarity and environmental sustainability (Maikhuri et al. 2000), (3) elongation of restoration project duration without raising the quantum of financial support, (4) arbitrary selection of households for availing government incentives, and (5) lack of commitments on community share in UN-REDD+ and other mechanisms of payments for ecosystem services. ILK on medicinal plants and new demand for them in national and overseas markets prompted policy uptake, but budget support was too low to induce any transformative change. Further, policy support was largely confined to cultivation in private farms, anticipating that wild populations would be restored. This was unsuccessful due to loopholes in the existing mechanisms of checking illicit harvests and their marketing (Rao et al. 2015). Failure of policy uptake for long-term support for participatory-adaptive restoration and for synergising forest conservation, forest restoration, agricultural development and socio-economic upliftment underscores a need for effective interactions among stakeholders: people, researchers, industrialists, traders and government officials. This failure seems to be the root cause of the lack of competitiveness of current forest restoration pathways, nullification of restoration-mediated carbon sequestration by agricultural abandonment-mediated emissions, and people's perceptions about the unfair sharing of benefits from new products.

Voluntary maintenance of the trial area despite poor survival of medicinal herbs and the ineffectiveness of alder in checking wildlife intrusions suggest that people value whole-hearted efforts more than their outcomes (Andrews and Borgerhoff Mulder 2018). Voluntary maintenance of the trial from the eighth year onwards was a sort of reciprocation for external support to the satisfaction of the people. Participation merely as wage earners resulted in unproductive investment in top-down restoration planting in the absence of a sense of ownership, responsibility and accountability among people and law enforcement (Schultz et al. 2012; Lyver et al. 2019; Reyes-Garcia et al. 2019). Discontentment among people due to neglect of their genuine concerns may turn into mass movements, like the ones in the 1920s forcing government to create community forests, in 1970s to ban logging even by its agencies in natural forests and to restore ecotourism, for example, in the Nanda Devi Biosphere Reserve (Maikhuri et al. 2000; Rao et al. 2015).

Assuming persistence of a net above-ground accumulation rate of $0.75 \mathrm{Mg} \mathrm{C} \mathrm{ha}^{-1}$ year $^{-1}$ observed at the end of the 20th year, it will take 210 years to restore $\mathrm{C}$ stock in the temperate intact Himalayan forest compared to 50-100 years in tropical forests (Marin-Spiotta et al. 2007; Wheeler et al. 2016; Lewis et al. 2019). Recovery in species richness was faster than carbon stock due to planting of a large number of species and minimal weeding. Active restoration is more expensive than passive restoration but a necessity in a biodiversity hotspot like Himalaya with 
intense limitations of propagule dispersal, viable soil seed banks and safe sites in shallow-gravelly soils on steep slopes. This study also underscores a need for treating cultural landscapes (Takeuchi et al. 2014; Reed et al. 2016) rather than just forests (Vanderhaegen et al. 2015) as spatial units, and for clarity on accounting of below-ground and harvested biomass carbon pools, and for time scale in determining payments for ecosystem services.

\subsection{Conclusions}

The present long-term location-specific study shows that nature and outcomes of participation of local people in forest restoration would vary in space and time depending on the socio-ecological conditions. Our field visits during the 2011-2019 period after systematically analysing the landscape for 20 years suggest the persistence of agricultural abandonment, restoration failure beyond the trial area, conservation of intact forest and the mindset of higher social status of urban livelihoods. The present study unveils the following practices for transformative change to achieve national or global targets:

- Nesting restoration in participatory long-term adaptive and integrated landscape and livelihood enhancement programmes;

- Coupling commodity production with bioprospecting, manufacturing and marketing;

- Formally involving communities in planning, monitoring and financial management;

- Assuring funding until restoration becomes an additional source of material/ income benefits to people;

- Limiting funding to inputs unaffordable by people with a condition of peopleresearcher joint monitoring after cessation of funding;

- Stimulating the inquisitive minds of people by informing them of the scientific implications of their ILK, as well as that evolved by other communities;

- Convincing policymakers to provide scientific foundations for stands/actions in open domain, and necessary support for the development of a network of "model restoration landscapes" co-managed by local people, researchers, traders and industrialists, and to commit a fair share to communities in payments for ecosystem services;

- Promoting condition/performance-based incentives/subsidies/rewards/compensation at multiple spatial (household, village, and village cluster) and temporal (short, medium, and long-term) scales. 


\section{References}

Adnan, M., \& Hölscher, D. (2011). Medicinal plants in old-growth, degraded and regrowth forests of NW Pakistan. Forest Ecology and Management, 261, 2105-2114.

Andrews, J., \& Borgerhoff Mulder, M. (2018). Cultural group selection and design of REDD+: insights from Pemba. Sustainability Science, 13, 93-107.

Ashton, M. S., Gunatilleke, I. A. U. N., Gunatilleke, C. V. S., Tennakoon, K. U., \& Ashton, P. S. (2014). Use and cultivation of plants that yield products other than timber from South Asian tropical forests, and their potential in forest restoration. Forest Ecology and Management, 329, 360-374.

Barr, C. M., \& Sayer, J. A. (2012). The political economy of reforestation and forest restoration in Asia-Pacific: Critical issues for REDD+. Biological Conservation, 154, 9-19.

Baynes, J., Herbohn, J., Smith, C., Fisher, R., \& Bray, D. (2015). Key factors which influence the success of community forestry in developing countries. Global Environmental Change, 35, 226-238.

Berkes, F. (2009). Evolution of co-management: Role of knowledge generation, bridging organizations and social learning. Journal of Environmental Management, 90, 1692-1702.

Bhadauria, T., Kumar, P., Kumar, R., Maikhuri, R. K., Rao, K. S., \& Saxena, K. G. (2012). Earthworm populations in a traditional village landscape in Central Himalaya, India. Applied Soil Ecology, 53, 83-93.

Brandt, J. S., Allendorf, T., Radeloff, V., \& Brooks, J. (2017). Effects of national forestmanagement regimes on unprotected forests of the Himalaya. Conservation Biology, 31, $1271-1282$.

Buffum, B., Gratzer, G., \& Tenzin, Y. (2008). The sustainability of selection cutting in a late successional broadleaved forest in Bhutan. Forest Ecology and Management, 256, 2084-2091.

Burton, P. J. (2014). Consideration for monitoring and evaluating forest restoration. Journal of Sustainable Forestry, 33, S149-S160.

Chazdon, R. L., Brancalion, P. H. S., Laestadius, L., Bennett-Curry, A., Buckingham, K., Kumar, C., Moll-Rocek, J., Vieira, I. C. G., \& Wilson, S. J. (2016). When is a forest a forest? Forest concepts and definitions in the era of forest and landscape restoration. Ambio, 45, 538-550.

Derak, M., Cortina, J., Taiqui, L., \& Aledo, A. (2018). A proposed framework for participatory forest restoration in semiarid areas of North Africa. Restoration Ecology, 26, S18-S25.

Dudley, N., Bhagwat, S. A., Harris, J., Maginnis, S., Moreno, J. G., Mueller, G. M., Oldfield, S., \& Walters, G. (2018). Measuring progress in status of land under forest landscape restoration using abiotic and biotic indicators. Restoration Ecology, 26, 5-12.

Evans, K., Guariguata, M. R., \& Brancalion, P. H. S. (2018). Participatory monitoring to connect local and global priorities for forest restoration. Conservation Biology, 32, 525-534.

Forest Survey of India. (2019). India State of Forest Report 2019, Ministry of Environment, Forests and Climate Change, Government of India, Dehradun, India.

Guariguata, M. R., Garcia-Fernandez, C., Sheil, D., Nasi, R., Herrero-Jauregui, C., Cronkelton, P., \& Ingram, V. (2010). Compatability of timber and non-timber forest produce management in natural tropical forests: Perspectives, challenges and opportunities. Forest Ecology and Management, 259, 237-245.

He, J., Zhou, Z., Weyerhaeuser, H., \& Xu, J. (2009). Participatory technology development for incorporating non-timber forest products into forest restoration in Yunnan, Southwest China. Forest Ecology and Management, 257, 2010-2016.

IPBES. (2019). Summary for policymakers of the global assessment report on biodiversity and ecosystem services of the Intergovernmental Science-Policy Platform on Biodiversity and Ecosystem Services. Bonn, Germany: IPBES Secretariat.

Le, H. D., Smith, C., Herbohn, J., \& Harrison, S. (2012). More than just trees: Assessing reforestation success in tropical developing countries. Journal of Rural Development, 28, 5-19.

Lewis, T., Verstraten, L., Hogg, B., Wehr, B. J., Swift, S., Tindale, N., Menzies, N., Dalal, R. C., Bryant, P., Francis, B., \& Smith, T. E. (2019). 'Reforestation of agricultural land in the tropics: 
The relative contribution of soil, living biomass and debris pools to carbon sequestration. Science of the Total Environment, 649, 1502-1513.

Liu, S., Dong, Y., Cheng, F., Coxixo, A., \& Hou, X. (2016). Practices and opportunities of ecosystem service studies for ecological restoration in China. Sustainability Science, 11, 935-944.

Lyver, P. O. B., Richardson, S. J., Gormley, A. M., Timoti, P., Jones, C. J., \& Tahi, B. L. (2019). Complementarity of indigenous and western scientific approaches for monitoring forest state. Ecological Applications, 28, 1909-1923.

Maikhuri, R. K., Nautiyal, S., Rao, K. S., Chandrasekhar, K., Gavali, R., \& Saxena, K. G. (2000). Analysis and resolution of protected area-people conflicts in Nanda Devi Biosphere Reserve, India. Environmental Conservation, 27, 43-53.

Maikhuri, R. K., Rao, K. S., \& Saxena, K. G. (2004). Bioprospecting of wild edibles for rural development in the Central Himalayan Mountains of India. Mountain Research and Development, 24, 110-113.

Marin-Spiotta, E., Ostertag, R., \& Silver, W. L. (2007). Long term patterns of tropical reforestation: Plant community composition and aboveground biomass accumulation. Ecological Applications, 17, 828-839.

Pandey, S. S., Maraseni, T. N., \& Cockfield, G. (2014). Carbon dynamics in different vegetation dominated community forests under REDD+. Forest Ecology and Management, 327, 40-47.

Rao, K. S., Maikhuri, R. K., \& Saxena, K. G. (1999). Participatory approach to rehabilitation of degraded forestlands: A case study in high altitude village of Indian Himalaya. International Tree Crops Journal, 10, 1-17.

Rao, K. S., Saxena, K. G., \& Tiwari, B. K. (2015). Biodiversity, climate change and livelihood in the Indian Himalaya: An overview. Dehradun, India: Bishen Singh Mahendra Pal Singh.

Reed, J., Van Vianen, J., Deakin, E. L., Barlow, J., \& Sunderland, T. (2016). Integrated landscape approaches to managing social and environmental issues in the tropics: Learning from the past to guide the future. Global Change Biology, 22, 2540-2554.

Reyes-Garcia, V., Fernandez-Llamazares, A., McElwee, P., Molnar, Z., Öllerer, K., Wilson, S. J., \& Brondizo, E. S. (2019). The contributions of indigenous peoples and local communities to ecological restoration. Restoration Ecology, 27, 3-8.

Rudel, T. K., Coomes, O. T., Moran, E., Achard, F., Angelsen, A., Xu, J., \& Lambin, E. (2005). Forest transitions: Towards a global understanding of land use change. Global Environmental Change, 15, 23-31.

Schultz, C. A., Jedd, T., \& Beam, R. D. (2012). The collaborative forest landscape restoration programme: A history and overview of the first projects. Journal of Forestry, 110, 381-391.

Semwal, R. L., Nautiyal, S., Sen, K. K., Rana, U., Maikhuri, R. K., Rao, K. S., \& Saxena, K. G. (2004). Patterns and ecological implications of agricultural land-use changes: A case study from central Himalaya, India. Agriculture, Ecosystems and Environment, 102, 81-92.

Semwal, R. L., Nautiyal, S., Maikhuri, R. K., Rao, K. S., \& Saxena, K. G. (2013). Growth and carbon stocks of multipurpose tree species plantations in degraded lands in Central Himalaya, India. Forest Ecology and Management, 310, 450-459.

Sharma, C. M., Baduni, N. P., Gairola, S., Ghildiyal, S. K., \& Suyal, S. (2010). Tree diversity and carbon stocks of some major forest types of Garhwal Himalaya, India. Forest Ecology and Management, 260, 2170-2179.

Stanturf, J. A., Palik, B. J., \& Dumroese, R. K. (2014). Contemporary forest restoration: A review of emphasizing function. Forest Ecology and Management, 331, 292-323.

Takeuchi, K., Elmqvist, T., Hatakeyama, M., Kauffman, J., Turner, N., \& Zhou, D. (2014). Using sustainability science to analyse socio-ecological restoration in NE Japan after the great earthquake and tsunami of 2011. Sustainability Science, 9, 513-526.

Vanderhaegen, K., Verbist, B., Hundera, K., \& Muys, B. (2015). REALU vs REDD+: Carbon and biodiversity in the Afromontane landscapes of SW Ethiopia. Forest Ecology and Management, $343,22-33$. 
Wakeel, A., Rao, K. S., Maikhuri, R. K., \& Saxena, K. G. (2005). Forest management and land use/cover changes in a typical micro watershed in the mid elevation zone of Central Himalaya, India. Forest Ecology and Management, 213, 229-242.

Wheeler, C. E., Omeja, P. A., Chapman, C. A., Glipin, M., Tumwesigye, C., \& Lewis, S. L. (2016). Carbon sequestration and biodiversity following 18 years of active tropical forest restoration. Forest Ecology and Management, 373, 44-55.

Yami, M., Mekuria, W., \& Hauser, M. (2013). The effectiveness of village bylaws in sustainable management of community-managed exclosures in Northern Ethiopia. Sustainability Science, 8 , 73-86.

The opinions expressed in this chapter are those of the author(s) and do not necessarily reflect the views of UNU-IAS, its Board of Directors, or the countries they represent.

Open Access This chapter is licenced under the terms of the Creative Commons Attribution 3.0 IGO Licence (https://creativecommons.org/licenses/by/3.0/igo/), which permits use, sharing, adaptation, distribution and reproduction in any medium or format, as long as you give appropriate credit to UNU-IAS, provide a link to the Creative Commons licence and indicate if changes were made.

The use of the UNU-IAS name and logo, shall be subject to a separate written licence agreement between UNU-IAS and the user and is not authorised as part of this CC BY 3.0 IGO licence. Note that the link provided above includes additional terms and conditions of the licence.

The images or other third party material in this chapter are included in the chapter's Creative Commons licence, unless indicated otherwise in a credit line to the material. If material is not included in the chapter's Creative Commons licence and your intended use is not permitted by statutory regulation, or exceeds the permitted use, you will need to obtain permission directly from the copyright holder. 